\title{
COVID-19 PCR Testi Veri Analizinde CAtenA Smart PCR Bioinformatik Programının Sunduğu Ön Değerlendirme Sonuçlarının Uzman Sonuçları ile Uyumunun Araştırılması
}

\author{
Ayşe Rüveyda Uğur ${ }^{1 *}$, Abdulkadir Taşdelen ${ }^{2}$ \\ $\mathbf{1}^{*}$ Konya Şehir Hastanesi, Tbbi Mikrobiyoloji, Konya, Türkiye (ORCID: 0000-0002-9622-6404)), ayserugur@gmail.com \\ 2 Karabük Üniversitesi, TOBB Teknik Bilimler Meslek Yüksekokulu, Karabük, Türkiye (ORCID: 0000-0003-4402-1463), abdulkadirtasdelen@karabuk.edu.tr
}

(International Symposium on Multidisciplinary Studies and Innovative Technologies (ISMSIT) 2021 - 21-23 October 2021)

(DOI: 10.31590/ejosat.1024190)

ATIF/REFERENCE: Uğur, A.R. \& Taşdelen, A. (2021). COVID-19 PCR Testi Veri Analizinde CAtenA Smart PCR Bioinformatik Programının Sunduğu Ön Değerlendirme Sonuçlarının Uzman Sonuçları ile Uyumunun Araştırılması. Avrupa Bilim ve Teknoloji Dergisi, (29), 327-330.

$\ddot{\mathbf{O z}}$

Amaç: Dünya Sağlık Örgütü tarafından COVID-19 için standart tanı yöntemi olarak bildirilen yöntemler arasında en yaygın kullanılanı, SARS-CoV-2 real time polimeraz zincir reaksiyonu (polymerase chain reaction, PCR) testidir. Yöntem uygulandıktan sonra, PCR veri dosyalarının uzman hekim tarafından analiz edilerek sonuçların web tabanlı Laboratuvar Bilgi Yönetim Sistemi'ne aktarılması gerekmektedir. Bu testlerin hızlı şekilde sonuçlandırılması ve sisteme hatasız olarak aktarılması COVID-19 tanı, tedavi ve takibi için oldukça önemli bir basamaktır. CAtenA Smart PCR programı, PCR veri dosyalarını yapay zeka ile değerlendirerek uzman onayına sunan ve onaylanmış sonuçları Laboratuvar Bilgi Yönetim Sistemi’ne aktarabilen web tabanlı yerli bir biyoinformatik programdır. Bu çalışmanın amacı, CAtenA Smart PCR programı tarafından gerçekleştirilen ön değerlendirme sonuçlarının uzman hekim analiz sonuçları ile uyumunun araştırılmasıdır.

Materyal-Metot: Bu amaçla, Meram Devlet Hastanesi COVID-19 PCR Laboratuvarı'nda real time PCR cihazında (Bio-Rad CFX96 Touch, Singapore) çalışılmış 846 PCR testi, yapay zeka kullanan biyoinformatik programı CAtenA Smart PCR'ın (Ventura, Ankara, Türkiye) sunduğu ön değerlendirme ve uzman analiz sonuçları açısından istatistiksel olarak karşılaştırılmıştır.

Bulgular ve Sonuç: CAtenA Smart PCR programının verdiği negatif ön değerlendirme sonuçlarının uzman analizi ile \%100, pozitif sonuçların ise \%97.7 uyum sağladığı belirlenmiştir. CAtenA'nın PCR tekrarı önerdiği 84 test sonucunun \%96.4'ü uzman analizi tarafından negatif; \%3.6'sı pozitif olarak sonuçlandırılmıştır. Yapılan McNemar-Bowker istatistik analizine göre yapay zeka tabanlı CAtenA ile uzman analizi arasında anlamlı bir fark belirlenmiştir $\left(\chi^{2}=84,2 ; p=0,0001\right)$. Sonuç olarak, uzman analizi olmadan yapılacak test onaylarında düşük de olsa hatalı pozitif sonuç onaylama riski olduğu, test tekrarlarının ise ek maliyete ve zaman kaybına neden olacağı düşünülmüştür. CAtenA'da kullanılan PCR analizinin özellikle test tekrarları konusunda iyileştirilmesi gerektiği önerisi getirilmiştir.

Anahtar Kelimeler: COVID-19, SARS-CoV-2, PCR, CAtenA, yapay zekâ, uzman analizi.

\section{Assessment of the Compatibility of the Preliminary Analysis Results of the CAtenA Smart PCR Bioinformatics Program with the Expert Results in COVID-19 PCR Test Data Analysis}

\begin{abstract}
Objective: SARS-CoV-2 real time polymerase chain reaction (PCR) assay, one of the procedures reported by the World Health Organization as the standard diagnostic method for COVID-19, is the most extensively used method in diagnostic laboratories. When the assay is accomplished, the PCR data file is analyzed by a specialist. Thereafter, the approved results are submitted into the webbased Laboratory Information Management System. Fast analysis of the PCR data and precise submission of the results to the laboratory management system are critical for the diagnosis, treatment, and monitoring of COVID-19 patients. CAtenA Smart PCR is a web-based bioinformatics tool that uses artificial intelligence to analyze PCR data files and offer results for expert approval. Then it transmits the approved results to the Laboratory Information Management System. The aim of this study is to investigate the compatibility of the preliminary results derived from the CAtenA Smart PCR program with the expert results.
\end{abstract}

\footnotetext{
* Sorumlu Yazar: Konya Şehir Hastanesi, Tıbbi Mikrobiyoloji, Konya, Türkiye, ORCID: 0000-0002-9622-6404, ayserugur@gmail.com
} 
Material and Methods: Overall 846 PCR data, performed in the COVID-19 PCR Laboratory at Meram State Hospital, were analyzed by the CAtenA Smart PCR (Ventura, Ankara, Turkey) and by an expert specialist. The results were assessed statistically in terms of the preliminary evaluation and expert analysis.

Results and Conclusion: The CAtenA Smart PCR program's negative preliminary results were found to be $100 \%$ compatible with the expert analysis, as were $97.7 \%$ of the positive results. Te expert analysis concluded that $96.4 \%$ of the 84 test results for which CAtenA indicated re-run were negative, whereas $3.6 \%$ were positive. There was a significant difference between the artificial intelligence-based CAtenA Smart PCR program and the expert analysis using the McNemar-Bowker statistical analysis $\left(\chi^{2}=84.2 ; \mathrm{p}=0.0001\right)$. In conclusion, without expert analysis, we propose that there could be false positive test results. Also, test repetitions would increase the cost and result in additional turnaround time. We suggest that the PCR analysis performed by CAtenA should be enhanced, particularly in terms of test re-runs.

Keywords: COVID-19, SARS-CoV-2, PCR, CAtenA, artificial intelligence, expert analysis.

\section{Giriş}

Çin'in Wuhan şehrinde, 2019 yılının Aralık ayında ilk kez ortaya çıkan SARS-CoV-2 virüsünün neden olduğu COVID-19 enfeksiyonu, dünya genelinde 4 ve 5 . dalgalarla etkisini sürdürmeye devam eden sıradışı bir pandemiye neden olmuştur (Liu et al., 2020). Dünya Sağlık Örgütü tarafından COVID-19 standart tanısının nükleik asit çoğaltma yöntemi ile konulabileceği bildirilmiştir (WHO, 2020). Bu yöntemler arasında en yaygın kullanılanı, SARS-CoV-2 real time polimeraz zincir reaksiyonu (polymerase chain reaction, PCR) testidir (Sule \& Oluwayelu., 2020). Yöntem uygulandıktan sonra, PCR veri dosyalarının uzman hekim tarafından analiz edilerek sonuçların web tabanlı Laboratuvar Bilgi Yönetim Sistemi'ne aktarılması gerekmektedir. Pandemi ile beraber açılan COVID-19 PCR tanı laboratuvarlarında test hizmetleri $7 / 24$ gerçekleştirilmekte ve yoğun bir iş akışı devam etmektedir. Bu testlerin hızlı şekilde sonuçlandırılması ve hatasız olarak sisteme aktarılması COVID19 tanı, tedavi ve takibi için oldukça önemli bir basamaktır (Sreepadmanabh et al, 2021). Machine learning, deep learning gibi yapay zeka içerikli programlar, klinik laboratuvarlarda işlenen karmaşık ve büyük veri setlerinin analiz edilmesine olanak sağlayarak sağlık sisteminin gelişmesine katkıda bulunmaktadır (Tasdelen \& Sen, 2021; Peiffer-Smadja et al., 2020). Özelllikle görüntü analizine dayalı Gram boyama, gaita mikroskopisi değerlendiren ve dijital bakteri kültürlerinin plaklardan okuyan uygulamalar başarıyla kullanılmaktadır (Rhoads et al., 2015).

Son zamanlarda yapay zeka Mikrobiyoloji laboratuvarlarında görüntü analizi dışındaki çeşitli veri kaynakları ve uygulamalarda yerini almaya başlamıştır (Smith et al., 2020; Asada et al., 2021). Matrix-assisted laser desorption-ionization/time of flight mass spectrometry (MALDI-TOF) kütle spektrometri ve tüm gen analizi verilerinin yapay zeka yardımıyla işlenmesi Mikrobiyoloji alanında yeni bir çığır açmıştır (van Oosten \& Klein, 2020). CAtenA Smart PCR (Ventura, Ankara, Türkiye), PCR veri dosyalarını yapay zeka ile değerlendirerek uzman onayına sunan ve onaylanmış sonuçları Laboratuvar Bilgi Yönetim Sistemi'ne aktarabilen web tabanlı biyoinformatik bir programdır (Ventura, 2020). Bu anlamda CAtenA, uzman hekime testlerin hizlı sonuçlandırılmasında yardımcı olmayı amaçlamaktadır.

$\mathrm{Bu}$ çalışmanın amacı, CAtenA Smart PCR programı tarafından gerçekleştirilen ön değerlendirme sonuçlarının uzman hekim analiz sonuçlarına uyumunun araştırılmasıdır.

\section{Materyal ve Metot}

\subsection{PCR Testlerinin Analizi}

Meram Devlet Hastanesi COVID-19 PCR Laboratuvarı'nda 1 Ekim 2021-1 Kasım 2021 tarihlerinde çalışılmış her biri 94 hasta örneği ve iki adet iç kalite kontrol örneği içeren dokuz PCR çalışması CAtenA (Ventura, Ankara, Türkiye) yapay zeka sistemine online olarak yüklendi. Bir Tibbi Viroloji uzmanı program üzerinden PCR verilerini analiz etti. Programın ön değerlendirme sonuçları ve uzman sonuçları elektronik ortama kaydedildi. İç kalite kontrol olan negatif ve pozitif kontroller değerlendirme dişı tutuldu. Böylece 846 PCR test sonucu çalışmaya dahil edildi.

Araştırmanın yapılabilmesi için Necmettin Erbakan Üniversitesi Bilimsel Araştırmalar Etik Kurulu'ndan etik onay alınmıştır (Karar no: 2021/3510 (7806).

\subsection{1. İstatiksel Analiz}

Sonuçlar SPSS 22 programı kullanılarak McNemarBowker istatistik testi ile analiz edildi. $\mathrm{P}<0.5$ istatistiksel olarak anlamlı kabul edildi (Tablo 2).

\section{Araştırma Sonuçları ve Tartışma}

\subsection{Bulgular}

CAtenA'nın verdiği negatif ön değerlendirme sonuçlarının uzman analizi ile \%100, pozitif sonuçların ise \%97.7 uyum sağladığı belirlenmiştir. CAtenA'nın PCR tekrarı önerdiği 84 test sonucunun \%96.4'ü uzman analizi tarafindan negatif, \%3.6's1 pozitif olarak sonuçlandırılmıştır. CAtenA'nın test tekrarı önerisinde bulunduğu örneklerin uzman analizi ile \%0 uyum sağladığı tespit edilmiştir. Tüm testler göz önünde tutulduğunda CAtenA'nın uzman analizi ile \%90.1 uyumlu olduğu belirlendi (Tablo 1.). Yapılan McNemar-Bowker istatistik analizine (Tablo 2) göre yapay zeka tabanlı CAtenA ile uzman analizi arasında anlamlı bir fark belirlenmiştir $\left(\chi^{2}=84,2 ; p=0,0001\right)$. 
European Journal of Science and Technology

Tablo 1. CAtenA smart PCR programı ve uzman analizi ile yapılan PCR test sonuçlarının karşılaştırılması.

\begin{tabular}{lllll|ll}
\hline \multirow{2}{*}{ Sonuç } & & \multicolumn{2}{l}{ Uzman analizi } & & \\
\cline { 3 - 6 } CAtenA & Negatif & Say1 & 541 & 0 & 0 & 541 \\
& & Uyum (\%) & $\% 100,0$ & $\% 0,0$ & $\% 0,0$ & $\% 100,0$ \\
\cline { 2 - 6 } & Pozitif & Say1 & 3 & 216 & 2 & 221 \\
& Uyum (\%) & $\% 1,4$ & $\% 97,7$ & $\% 0,9$ & $\% 100,0$ \\
\cline { 2 - 6 } & Test Tekrar1 & Say1 & 81 & 3 & 0 & 84 \\
& & Uyum (\%) & $\% 96,4$ & $\% 3,6$ & $\% 0,0$ & $1 \% 00,0$ \\
\hline Toplam & Say1 & 625 & 219 & 2 & 846 \\
& & Uyum (\%) & $\% 73,9$ & $\% 25,9$ & $\% 0,2$ & $\% 100,0$ \\
\hline
\end{tabular}

Tablo 2. PCR test sonuçlarının CAtenA Smart PCR programı ile uzman analizi arasindaki istatistiksel analizi.

\begin{tabular}{lll|l}
\hline & Value & df & $\begin{array}{l}\text { Asemptomatik } \\
\text { fark (2-taraflı) }\end{array}$ \\
\hline $\begin{array}{l}\text { McNemar-Bowker Test } \\
\text { Geçerli test sayısı }\end{array}$ & 84,200 & 3 & 0,000 \\
\hline
\end{tabular}

\subsection{Tartışma}

Laboratuvarımızda çalıştığımız 846 PCR test verisini analiz ettiğimizde CAtenA ve uzman değerlendirmesi arasındaki uyumun \%90.1 olduğu belirlenmiştir. Test sonuçları negatif, pozitif ve test tekrarı olarak gruplandırıldığında ise negatif sonuçlar arasında $\% 100$ ve pozitif sonuçlar arasında $\% 97.7$ uyum gözlemlenirken, yapay zekanın test tekrarı önerisinde bulunduğu PCR testlerinin tamamı uzman tarafından negatif veya pozitif olarak sonuçlandırıldığı için analizler arasında $\% 0$ oranında uyum bulunmuştur. CAtenA programı, Türkiye, Özbekistan ve İtalya'da konumlanan çeşitli COVID-19 tanı laboratuvarlarında çalışılmış 4 milyonun üzerinde PCR test sonucu deneme amaçlı değerlendirilerek kullanıma sunulmuştur (Ventura, 2020). Üretici firma tarafindan gerçekleştirilen ön çalışma sonuçlarına göre, CAtenA ön değerlendirme sonuçlarının uzman analizi ile \%97,96 oranında uyumlu olduğu bildirilmiştir (Ventura, 2020). Bu çalışmada yer alan karşılaştırma sonuçlarından yola çıkarak elde ettiğimiz uyum oranı, firma tarafindan belirlenen uyum oranından daha düşük bulunmuştur.

Pandemi nedeniyle artan iş yükü, COVID-19 PCR laboratuvarlarında test sonuçlarının hızlı bir şekilde değerlendirilerek sonuç sistemine aktarılması konusunda aksamalara neden olabilmektedir. Bu nedenle geliştirilen CAtenA Smart PCR programı, kullanıcıya hızlı ve doğru sonuç konusunda yardımcı olabilecek bir programdır. Uzman hekim tarafindan sonuçlandırılan testlerin, yapay zeka ile analiz edilerek uzman hekimin tercihlerine göre sonuç önerileri sunabilmesi büyük bir avantajdır. Diğer yandan, programın kullanıma sunulmasından yaklaşık bir sene sonra gerçekleştirdiğimiz karşılaştırma bulguları göz önüne alındığında, CAtenA'nın test tekrarı önerisi konusunda geliştirilmeye ihtiyacı olduğu görülmektedir. Ayrıca, bulgularımıza göre program, düşük oranda da olsa yanlış pozitif sonuç önerisinde bulunabilmektedir. Yanlış pozitif sonuçlar gereksiz tedavi, karantina ve temaslı takibi, dolayısıyla gereksiz ekonomik maliyet ve iş gücü kaybı gibi negatif etkilere neden olmaktadır. Dolayısıyla yapay zekanın, pozitif sonuç önerileri konusunda de geliştirilmesi gerektiği vurgulanmıştır. PCR testleri sonuçlandırılırken en kötü senaryo, yanlış negatif sonuç vermektir. Yanlış negatif sonuçlar, tedavi alması gereken hastanın uygun şekilde tedavi almaması, asemptomatik pozitif bireylerin toplum içinde bulaştırıcılıklarının devam etmesi gibi önemli sorunlara neden olabilmektedir. Çalışmamızda CAtenA ile değerlendirilen test önerileri arasında yanlış negatif sonucun bulunmaması programın güvenilirliğini artırmaktadır. Bulgularımızın tamamı değerlendirildiğinde, COVID-19 PCR test sonuçlarının bioinformatik program kullanılarak onaylanmadan önce mutlaka uzman hekim kontrolünden geçmesi gerektiği gösterilmiştir.

CAtenA programının sunduğu avantajlardan bir diğeri, test sonuçlarının hatasız olarak Laboratuvar Bilgi Yönetim Sistemi'ne aktarılabilmesi ve bu konudaki post analitik hataların önüne geçilebilmesidir. Test sonuçlarının Laboratuvar Bilgi Yönetim Sistemi'ne manuel olarak yüklenmesi hasta bazlı veya toplu onay seçenekleri ile olabilmektedir. Test yükü fazla olan merkezler toplu onay seçeneğini kullanmayı tercih etmektedirler. Manuel veri girişlerinde herhangi bir hataya mahal vermemek için son derece dikkatli olmak ve her aşamada verilerin doğruluğu konusunda kontrol sağlamak gerekmektedir. Çalışma listelerinde yer alan barkodlama yöntemi ile CAtenA smart PCR programı herhangi bir manuel girișe gerek kalmadan hasta sonuçlarının doğrudan Laboratuvar Bilgi Yönetim Sistemi'ne aktarılmasına olanak vermektedir.

PCR veri analizi belli kurallarla yapılmasına rağmen, sonuçlar, mikrobiyoloji uzmanının kullanılan kit, sarf, cihaz tecrübesi ve çalışma kalitesi ile de yakından ilgilidir (Kuang et al., 2018). Bu nedenle CAtenA smart PCR programını kullanan çok sayıda mikrobiyoloji uzmanı aynı çalışmayı farklı değerlendirebilmektedir. Örneğin düşük pozitif olduğu düşünülen bir örnek tekrar çalışılabilmektedir. Çalışmamızda az sayıda uzman tarafından değerlendirilme yapılmış olması, araştırmamızın kısıtlılıklarından birisidir. Diğer bir kısıtlılığımız ise çalışmamızın kısa bir zaman diliminde tamamlanmış olmasıdır. Zaman içerisinde yapay zeka önerilerinin uzman tercihine göre değişip değişmediği ve önerilerde iyileşmenin olup olmadığı tarafımızdan değerlendirilememiş, CAtenA Smart PCR veri analizinde yalnızca anlık bir fotoğraf çekilebilmiştir. Daha çok uzman tarafından daha fazla PCR veri analizinin karşılaştırılması daha kesin sonuçlar elde edilmesini sağlayacaktır. 


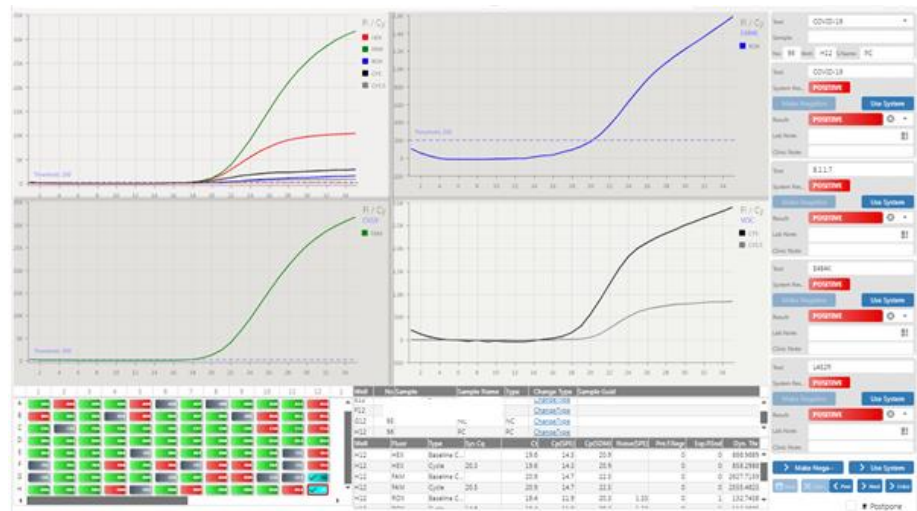

SSekil 1. CAtenA Smart PCR ile uzman onayına sunulmuş veri analizi. Çalışmada yeşil renkli kutucuklar negatif, kırmızılar pozitif, griler tekrarlanması gereken testleri göstermektedir. Mavi renkli kutucuklar negatif ve pozitif iç kalite kontrollerdir.

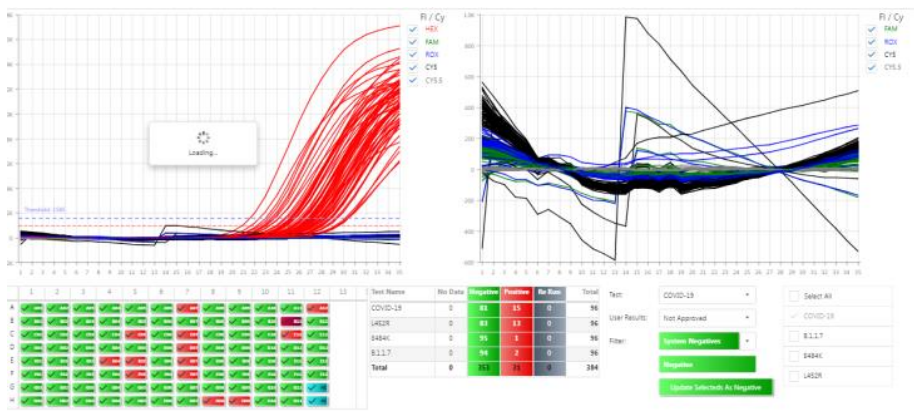

Şekil 2. Şekil 1.'de verilen PCR verisinin uzman analizi. Çalışmada yeşil renkli kutucuklar negatif, kırmızılar pozitif, griler tekrarlanmasi gereken testleri göstermektedir. Mavi renkli kutucuklar negatif ve pozitif iç kalite kontrollerdir. PCR test analiz önerisi uzman hekim tarafindan gözden geçirilerek nihai karar oluşturulmuştur.

\section{Sonuç}

Yapay zeka kullanan biyoinformatik veri analiz programı CAtenA'nın, negatif sonuçları tahmin etme konusunda \%100 başarılı olduğu, \%3.6 yanlış pozitif sonuç verdiği belirlenmiştir. CAtenA'nın PCR test tekrarı önerdiği örneklerin tamamı uzman tarafından negatif veya pozitif olarak değerlendirilmiştir. Elde ettiğimiz bulgular doğrultusunda, uzman analizi olmadan yapılacak test onaylarında düşük de olsa hatalı sonuç onaylama riski olduğu, test tekrarlarının ise ek maliyete ve zaman kaybına neden olacağı düşünülmüştür. CAtenA'da kullanılan PCR analizinin özellikle yanlış pozitif sonuç ve test tekrarları konusunda iyileştirilmesi gerektiği önerisi getirilmiştir.

\section{Kaynakça}

Asada, K., Kaneko, S., Takasawa, K., Machino, H., Takahashi, S., Shinkai, N., Shimoyama, R., Komatsu, M., \& Hamamoto, R.
(2021). Integrated Analysis of Whole Genome and Epigenome Data Using Machine Learning Technology: Toward the Establishment of Precision Oncology. Frontiers in oncology, 11, 666937. https://doi.org/10.3389/fonc.2021.666937

Kuang, J., Yan, X., Genders, A. J., Granata, C., \& Bishop, D. J. (2018). An overview of technical considerations when using quantitative real-time PCR analysis of gene expression in human exercise research. PloS one, 13(5), e0196438. https://doi.org/10.1371/journal.pone.0196438

Liu, Y. C., Kuo, R. L., \& Shih, S. R. (2020). COVID-19: The first documented coronavirus pandemic in history. Biomedical journal, 43(4), https://doi.org/10.1016/j.bj.2020.04.007

Peiffer-Smadja, N., Dellière, S., Rodriguez, C., Birgand, G., Lescure, F. X., Fourati, S., \& Ruppé, E. (2020). Machine learning in the clinical microbiology laboratory: has the time come for routine practice? Clinical microbiology and infection: the official publication of the European Society of Clinical Microbiology and Infectious Diseases, 26(10), 1300-1309. https://doi.org/10.1016/j.cmi.2020.02.006

Rhoads, D. D., Novak, S. M., \& Pantanowitz, L. (2015). A review of the current state of digital plate reading of cultures in clinical microbiology. Journal of pathology informatics, 6 , 23. https://doi.org/10.4103/2153-3539.157789

Smith, K. P., Wang, H., Durant, T.J.S., Mathison, B.A., Sharpeh, S.E., Kirby, J.E., et al. (2020). Application of artificial intelligence in clinical microbiology diagnostic testing. Clin. Microbiol. Newsletter. 42, 61-70.

Sreepadmanabh, M., Sahu, A. K., \& Chande, A. (2020). COVID19: Advances in diagnostic tools, treatment strategies, and vaccine development. Journal of biosciences, 45(1), 148. https://doi.org/10.1007/s12038-020-00114-6

Sule, W. F., \& Oluwayelu, D. O. (2020). Real-time RT-PCR for COVID-19 diagnosis: challenges and prospects. The Pan African medical journal,35(Suppl 2), 121. https://doi.org/10.11604/pamj.supp.2020.35.24258

Tasdelen, A., \& Sen, B. (2021). A hybrid CNN-LSTM model for pre-miRNA classification. Scientific reports, 11(1), 14125. https://doi.org/10.1038/s41598-021-93656-0

van Oosten, L. N., \& Klein, C. D. (2020). Machine Learning in Mass Spectrometry: A MALDI-TOF MS Approach to Phenotypic Antibacterial Screening. Journal of medicinal chemistry, 63(16),

8849-8856. https://doi.org/10.1021/acs.jmedchem.0c00040

Ventura. CAtenA Smart PCR. https://ventura.com.tr/?page_id=1528 (son ziyaret tarihi: 5 Ekim 2021).

Worl Health Organization. (2020, 17 January). Laboratory testing of 2019 novel coronavirus (2019-nCoV) in suspected human cases: interim guidance, 17 January 2020. https://www.who.int/publications/i/item/laboratory-testingof-2019-novel-coronavirus-(-2019-ncov)-in-suspectedhuman-cases-interim-guidance-17-january-2020 